\title{
CORPORATE SOCIAL RESPONSIBILITY
}

THE EFFICACY OF MATCHED ALLIANCES BETWEEN NOT-FOR-PROFITS AND MULTINATIONAL ENTERPRISES IN DEVELOPED AND EMERGING MARKETS

MARINILKA B. KIMBRO

(corresponding author)

Albers School of Business and Economics

Seattle University

Seattle, Washington, U.S.A.

kimbrom@seattleu.edu

AJAY T. ABRAHAM

Albers School of Business and Economics

Seattle University

Seattle, Washington, U.S.A.

abrahama@seattleu.edu

C. JAY LAMBE

Albers School of Business and Economics

Seattle University

Seattle, Washington, U.S.A.

lambecj@seattleu.edu

VICTORIA JONES

University of California, Irvine Irvine, California, U.S.A.

vljones@uci.edu 
Abstract. Responding to Pope Francis's appeals in Laudato si' and to societal pressures, multinational enterprises (MNEs; Dunning, 1977) are increasingly searching for ways to structure demands for corporate social responsibility (CSR). Previous literature, however, suggests that the positive effects of CSR initiatives are not certain; moreover, alliance-based CSR remains an understudied area. Therefore, we propose a model based on a "matched" alliance approach to increase the efficacy of, and positive response to, CSR initiatives. We argue that MNEs increase the legitimacy and/or business-process efficiency of CSR initiatives by partnering with not-for-profit (NFP; Schwenk, 1990) organizations in alliances that "match" common objectives with complementary capabilities, which in turn results in positive responses to CSR initiatives. We propose that CSR activities from the following matched alliances will result in more positive media coverage: between MNEs and NFPs, between a local MNE and local NFPs (vs. a foreign MNE and local NFPs), and between local MNEs and NFPs in an emerging (vs. developed) market. Our case and media-intensity analyses for Walmart's Katrina Assistance, Infosys's Campus Connect, and Unilever's Project Shakti span matched alliances between local and foreign MNEs in emerging and developed markets. Our findings document positive media coverage surrounding CSR initiatives whenever MNEs partner with matched local NFPs. In addition, positive media coverage is more for local rather than foreign MNEs, and for CSR initiatives in emerging, rather than developed, markets.

Keywords: alliances; CSR; CSR and legitimacy; CSR and media coverage; CSR in emerging markets; Laudato Si'; matched alliances; MNE; multinational enterprise; NFP; NFP and MNE alliances; not-for-profit

\section{INTRODUCTION}

There are too many special interests, and economic interests easily end up trumping the common good and manipulating information so that their own plans will not be affected.

The Holy Father's words are supported by ample evidence (e.g., Harriss-White, 2006; Wachtel, 1972); within this context, Laudato si' is the Catholic Church's call to solve this crisis (Francis, 2015). In similar fashion, a 2016 special report in Promotio Iustitiae takes the provocative position that the failure to alleviate poverty, considering that society has enough resources to do so, is an act of violence against the poor (Society of Jesus, 2016). Indeed, the scandals of firms engaging in dishonest business practices are evidence of a disheartening level of corporate 
"greed" - the marketing campaigns of tobacco firms, for example, deceptively featured endorsements from doctors about the benefits of cigarette consumption (e.g., Calfee, 1986). Corporate malfeasance, as the Holy Father notes, has caused extraordinary harm to society, with other recent examples including the Volkswagen emissions fraud and Apple sweatshops (Frost \& Burnett, 2007; Hakim \& Bradsher, 2015).

Responding reactively to crises calls for a spirit of resiliency (Brancatelli, 2016). Some firms engage proactively in activities that demonstrate corporate social responsibility (CSR); they comply with legal standards but also voluntarily undertake initiatives that result in social good. However, while there is evidence of the benefits of CSR as a positioning strategy for competitive product and brand differentiation (Varadarajan \& Menon, 1988) and image enhancement (e.g., Hsu, 2012), the links between CSR initiatives and positive external outcomes remain mixed (e.g., van Beurden \& Gössling, 2008). We propose two broad explanations for this mixture of evidence-one, which dominates the literature, is a market-attribution explanation, and the other, which is less explored, is a business process explanation.

With respect to market-attribution, not all CSR activities are perceived positively; thus, links between CSR initiatives and positive external outcomes are often tentative. The lack of positive effects can be explained as being due to stakeholders who feel that firms use CSR for "green-washing." In this context, CSR is no longer a "desired" attribute but a required one. Furthermore, as CSR is often global, its initiatives are colored by a country's culture and whether focal organizations are local (e.g., Choi, Chang, Li, \& Jang, 2016).

With respect to the business process explanation, multinational enterprises (MNEs; Dunning, 1977) and not-for-profit (NFP; Schwenk, 1990) organizations often engage in CSR activities through alliances. They may, however, lack the requisite resources especially in foreign markets, as well as good business processes which are especially important when structuring the CSR alliance. In relation to this, Elg, Ghauri, and Tarnovskaya (2008) propose a network/alliance matching approach with key "actors" to facilitate emerging-market entry. Matching in this context refers to agreements, alliances, and collaborations based on common goals and complementary resources. Therefore, although extant literature has investigated new theories of the firm (e.g., Costa \& Martí, 2012), our research is more aligned with new theories of CSR (Garriga \& Melé, 2004).

Our research question is to study the efficacy of MNE-NFP matched alliances. Using media coverage intensity analysis, we explore whether 
CSR activities of matched MNE-NFP alliances result in measurable positive media coverage, and we compare this effect for local versus foreign MNEs and in emerging versus developed markets. We build on instrumental theories of CSR (Garriga \& Melé, 2004) which suggest a positive perception of NFPs (Aaker, Vohs, \& Mogilner, 2010), and on the "matching" strategy proposed by Elg, Ghauri, and Tarnovskaya (2008). We expect that "matched" MNE-NFP alliances legitimize CSR activities and/or lead to better business processes, thereby resulting in positive outcomes that benefit society. Moreover, as many alliancebased CSR initiatives are global, we also build on Choi, Chang, Li, and Jang (2016) and on Van Beurden and Gössling (2008) and measure the media coverage of matched MNE-NFP CSR activities with local MNEs vis-à-vis foreign ones. We operationalize this construct by examining the effect of matched MNE-NFP CSR activities in the United States (developed market) and in India (emerging market). Here we study CSR activities of the following MNE-NFP alliances: Walmart-Red Cross relief efforts in the Katrina disaster (developed-local); Infosys-universities technology education initiative in India ("Campus Connect"; emerginglocal) and Unilever-government rural women empowerment initiative in India ("Project Shakti"; emerging-foreign). Our results suggest that the CSR activities of matched MNE-NFP alliances result in positive media coverage, and that positive media coverage is greater for local (vs. foreign) MNEs and in emerging (vs. developed) markets.

Our research contributes to the CSR literature, CSR best practices, and Jesuit social justice aims as follows: First, we expand the alliancebased CSR literature (Keys, Malnight, \& Van der Graaf, 2009). Second, CSR research tends to focus more on characteristics (e.g., for-profit vs. NFP) and tactics (e.g., presence vs. absence of CSR information; Torelli, Monga, \& Kaikati, 2012) that impact customer attitudes rather than on how strategies or business processes influence those characteristics. We address this gap by examining how strategic matching impacts factors that influence customer attitudes. Third, research on matching has neither been conducted in a CSR context nor empirically tested. We do both in domestic and foreign contexts, a welcome integration given that many alliance-based CSR initiatives are global in nature. Fourth, many CSR initiatives fail to meet their desired objectives (Browne \& Nuttall, 2013), and so this study provides guidance to enhance the performance of alliance-based CSR initiatives and further, therefore, the social justice aims of the Society of Jesus.

The commitment of firms to CSR initiatives that enhance global sustainability may lead to business success, brand recognition, and other competitive advantages of greater or lesser duration. Such positive outcomes may be important reasons why some firms engage in strategic 
partnerships and alliances to communicate and execute their CSR activities more effectively. Be that as it may, these corporate actions will directly or indirectly be the "fortunate by-products" of a much more important quest-achieving a socially just and sustainable world (Stoner, 2013).

\section{LITERATURE AND MODEL DEVELOPMENT}

\section{Matching: Linking MNE Resources with Local Needs for Positive CSR Outcomes}

Wettstein (2005) proposes that MNEs actively collaborate with governments as a moral responsibility and to solve complex problems. With MNEs expected to carry some of the burden of nation-states, then, it becomes paramount to identify a CSR strategy that meets MNE objectives and the demands of stakeholders. Cruz and Boehe (2010) identified four challenges for international CSR: local responsiveness, competitive advantage, worldwide learning, and global efficiencies. They suggest stakeholder collaboration as a way of addressing these challenges. Yuan, Bao, and Verbeke (2011) propose that collaborating for CSR provides benefits to the MNE, including access to complementary resources, cost reductions, and greater effectiveness, while not detracting much from the MNE's core business.

One approach to collaboration is "matching." Studying IKEA's entry into emerging markets, Elg, Ghauri, and Tarnovskaya (2008) elaborate on three components of matching: actors, activities, and resources. Actors are entities involved in the collaboration, activities are tasks that each actor contributes to the collaboration, and resources are exchanged among the actors (e.g., knowledge, facilities, and materials). In matching, each component should be complementary so that all parties gain through the collaboration. The authors distinguish between network theory, which is about business relationships, and matching, which is about relationships between for-profit and NFP actors such as governments, non-governmental organizations (NGOs), and community citizen groups.

Matching proposes that MNEs may find complementarities at three levels. At the global level, "matched" actors may be international interest groups or political institutions, and the exchange may include multilateral agreements, international standards for best practices, etc. Macro level "matches" may involve government, media, and interest groups. The micro level is local, and includes actors that assist with building local trust, demonstrating benefits to the community, and 
positive public relations. Thus, although designed for market entry, matching can also be applied to guide MNEs' CSR initiatives. Through it, MNEs fulfill their social contract and business objectives while helping NFP collaborators meet their goals.

Indeed, matching creates synergies between collaborators when applied to CSR. Non-business collaborators as such are natural allies to business in CSR, and matching can guide the selection of actors so that activities are more effective by identifying complementarities among actors, activities, resources, and objectives. In matching, however, MNEs also consider their business objectives in the development of CSR activities. Does the enterprise need public relations, employee engagement, government relations, consumer loyalty, or branding? Visibility is vital for accomplishing local objectives, and CSR activities should involve communication so that MNEs' CSR initiatives are recognized (Polonsky \& Jevons, 2009).

The MNE must also inventory its resources, and an efficient CSR initiative should not require additional investment-the ideal resources and capacity should be available, underutilized, and accessible when not needed for core operations. Some examples are: in-house design services between campaigns, the cafeteria kitchen between meal preparations, and an empty parking lot outside business hours.

Human resources are also among the most important firm resources. Local employees understand and are part of their local community; hence, the motivational benefits of local CSR activities are important reasons for MNEs to develop local CSR programs more actively.

As an example, an MNE producing athletic equipment may engage its employees as referees for an NFP that offers sport camps for low-income children. The NFP's core business is to provide sport activities, and the MNE collaborates to help the NFP. At the same time, the MNE benefits through employee satisfaction, community engagement, and branding while fostering a positive connection with the local market. The MNE's resources - the employee volunteers' time as well as providing snacks and t-shirts-are matched with the NFP's objectives to aid the community.

\section{Influence of Legitimacy and Matching on Positive CSR Outcomes}

We posit that the (sometimes conflicting) market perceptions of firms' motivations to engage in CSR (e.g., Delmas \& Burbano, 2011; Sen $\&$ Bhattacharya, 2001) are determined by market views of a firm's level of legitimacy. We argue that, ceteris paribus, if the market legitimizes a 
firm's motivation, it will result in greater positive outcomes (e.g., better brand image, increase in firm's value, etc.) and vice-versa. In other words, if the market perceives that a firm's CSR activities are a legitimate exercise of doing good, these CSR activities will be value-enhancing. On the other hand, if the market believes CSR activities to be green-washing, the activities will result in negative responses. Partnering with NFPs, therefore, is one way of attaining legitimacy.

Firms also tend to replicate their market-operation approach in CSR activities even though the stakeholders are very different (Husted \& Allen, 2006). By applying matching, MNEs can identify CSR collaborators whose goals and resources complement the MNEs', and then choose activities that complement their core business. A matching approach to CSR alliances between MNEs and NFPs, therefore, should lead to enhanced CSR outcomes on the firm and societal levels. Hence, we suggest the following:

Proposition 1: CSR activities from matched alliances of MNEs and NFPs will result in positive media coverage.

\section{Influence of Country Culture on Customer Perceptions and Positive CSR Outcomes}

Country culture also influences perceptions of CSR initiatives (e.g., Choi et al., 2016). Thus, while a basic tenet of social identity theory is that people identify with their in-group (Tajfel \& Turner, 1979), the degree of in-group identification varies across persons who possess different cultural orientations. For example, collectivists tend to identify more with the in-group (Ashforth \& Mael, 1996) and perceive that the boundary between the in-group and out-group is more distinctive and salient (Iyengar, Lepper, \& Ross, 1999). Stronger in-group identification is also linked to greater intergroup bias (e.g., Tajfel \& Turner, 1979) for individuals, firms, and products. Gürhan-Canli and Maheswaran (2000) found that Japanese customers (more collectivist) prefer Japanese products over foreign products regardless of product quality, whereas American customers (more individualist) care more about product superiority than country of origin. This suggests that intergroup bias should occur more among collectivistic (vs. individualistic) cultures. More specifically, collectivists are more likely to exhibit in-group favoritism through altruistic attribution for a domestic (vs. foreign) firm's CSR activities compared to individualists. Customer attitudes toward a firm are also largely determined by attributions of firm behavior (e.g., Ellen, Webb, \& Mohr, 2006). Attributions can occur due to insufficient trust or information (e.g., Nisbett \& Ross, 1980) because when trust is limited, 
suspicion of hidden motives encourages people to "give much thought to 'why' questions" (Fein, 1996: 165). Indeed, Gilbert and Malone (1995) show that customers care more about why firms are doing an activity than what the activity is. Therefore, as customers consistently show a lack of trust in firms, CSR activities might direct attention toward a firm's actual intentions (Ellen et al., 2006).

Moreover, although CSR is generally perceived as prosocial (Varadarajan \& Menon, 1988), customers may not view all firms engaging in CSR in the same way. If customers make altruistic attributions for firms' CSR activities, it may be because they believe that the firm is interested in society and may thus develop positive attitudes toward the firm (Ellen et al., 2006). If altruistic attributions are low, however, customers may perceive the firm less positively (Fein, 1996). In accordance with this, extant research has found that altruistic CSR attributions are related to positive consumption behaviors, and that not all CSR activities are associated with the same outcomes. For example, research shows that customers are more willing to buy a firm's products due to positive attributions when its CSR initiatives are well-aligned with its core business (Ellen et al., 2006). Similarly, Groza, Pronschinske, and Walker (2011) found that customers have elevated purchase intentions toward firms that demonstrate proactive (vs. reactive) CSR strategies since they make more altruistic attributions for proactive strategies.

By synthesizing the above research, we expect collectivists (vs. individualists) to make greater altruistic attributions for CSR activities of domestic (vs. foreign) MNEs, which should then cause them to form congruently positive attitudes. Moreover, since people in emerging markets tend to be more collectivist in general (Hofstede, 2001), we posit the following:

Proposition 2: CSR activities from matched alliances between a local MNE and local NFPs will result in greater positive media coverage (vs. a foreign MNE matched with local NFPs).

Proposition 3: CSR activities from matched alliances between local MNEs and local NFPs in an emerging (vs. developed) market will result in greater positive media coverage.

Figure 1 below summarizes our conceptual framework. 


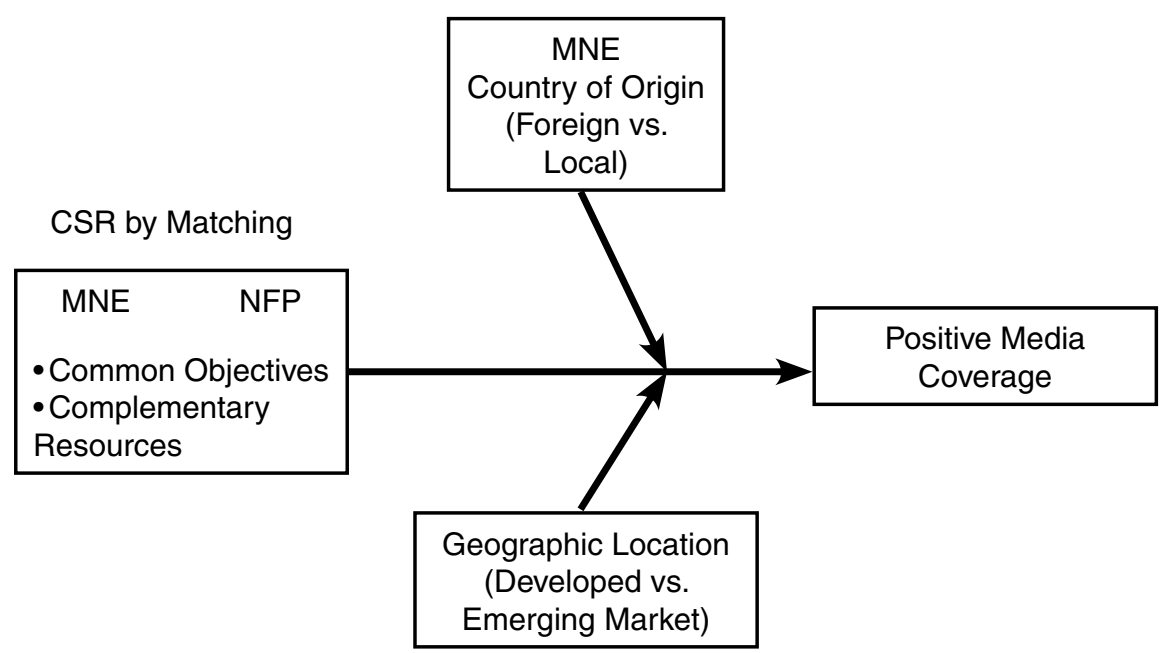

FIGURE 1: Conceptual Framework

\section{METHODOLOGY AND RESULTS}

\section{Case Studies: Leveraging CSR Activities through Matching}

The case studies in this section showcase examples of matched alliances between corporations and NFPs that result in successful CSR activities in various settings. Each case study identifies the matched actors, the resources contributed, the objectives met, the activities in which the matched actors engage, and the impact these activities have in the local community. The projects described below are examples of effective CSR activities that meet local needs and create benefits through matched alliances with NFPs.

We selected these specific case studies to investigate our three propositions. For example, Proposition 2 requires comparing CSR by a matched alliance with local MNEs and CSR by a matched alliance with foreign MNEs, while Proposition 3 requires comparing CSR by a matched alliance in a developed vs. emerging market. Therefore, we selected one case study for a local MNE (Walmart) in a developed market (United States), one for a local MNE (Infosys) in an emerging market (India), and one for a foreign MNE (Unilever) in an emerging market (India). We proceeded with this partial factorial design as we were unable to locate a comparable case study for a foreign MNE in a developed market.

MILLIONS IN CORPORATE-IMAGE advertising in the past year failed to do much to help Wal-Mart's reputation, shredded by disappointing business 
results, news stories about its lowest-paid workers getting Medicaid and food stamps and charges of embezzlement against its multimillionaire former No. 2 executive. But now, in the wake of Hurricane Katrina, Wal-Mart is getting the kind of advertising no marketer can buy. As local, state and federal officials looked flummoxed by the worst natural disaster in U.S. history, Wal-Mart had 45 truckloads of relief supplies ready to ship before Katrina made landfall. In a tearful interview on NEC's "Meet the Press" on Sept. 4, the president of Louisiana's Jefferson Parish said: "If the American government would have responded like Wal-Mart ... we wouldn't be in this crisis." Later, the mayor of Kenner, La., suggested on MSNBC that the Federal Emergency Management Administration should learn logistics from Walmart. (Neff, 2005)

With its unique initiative, Infosys (launched 2004) has reached out to 502 engineering colleges in India as well as from abroad while benefiting 3,000 faculty members in an effort to firm up India's soft skills. Tech titans have often talked of the skill gap created by the disconnect between the demand of the IT industry and the supply of industryready recruits. As India moves towards becoming a global leader in IT, management and engineering colleges along with industry have realised the need to scale up quality students to meet the growing demand of the sector. Infosys's Campus Connect programme, started in 2004, is a unique industry-academia initiative that aims to overcome this by creating a vibrant pool of future engineering graduates. (David, 2009)

Started in late 2000, Project Shakti has extended Hindustan Unilever's reach into 80,000 of India's 638,000 villages, on top of about 100,000 served by conventional distribution methods, according to Dalip Sehgal, the company's director of new ventures. The project accounts for nearly 15 percent of rural sales. The women typically earn between $\$ 16$ and $\$ 22$ per month, often doubling their household income, and tend to use the extra money to educate their children. (Lancaster, 2006: A.13)

For each of the three cases examined above (Walmart's Katrina Assistance, Infosys's Campus Connect, and Unilever's Project Shakti), Tables 1 through 3 report the 1) matched actors, 2) resources contributed, 3 ) activities in which the actors engaged, and 4) impact in the local community (Infosys, 2017a, 2017b; Unilever, 2001, 2005). 


\begin{tabular}{|c|c|c|c|c|}
\hline Actors & Resources & Activities & Objectives & Results \\
\hline Walmart & $\begin{array}{c}\text { Distribution } \\
\text { infrastructure }\end{array}$ & $\begin{array}{c}\text { Deliver } \\
\text { emergency } \\
\text { supplies }\end{array}$ & $\begin{array}{c}\text { Positive PR } \\
\text { and favor } \\
\text { with local } \\
\text { government }\end{array}$ & $\begin{array}{c}\text { Extensive } \\
\text { press, } \\
\text { customer and } \\
\text { employee } \\
\text { loyalty }\end{array}$ \\
\hline $\begin{array}{c}\text { Red Cross, } \\
\text { local } \\
\text { government } \\
\text { agencies, } \\
\begin{array}{c}\text { and other } \\
\text { non-profit } \\
\text { organizations }\end{array}\end{array}$ & $\begin{array}{c}\text { knowledge } \\
\text { and access }\end{array}$ & $\begin{array}{c}\text { Identification } \\
\text { of needs, } \\
\text { community } \\
\text { access }\end{array}$ & Disaster relief & $\begin{array}{c}\text { Fulfill duty } \\
\text { of disaster } \\
\text { relief, improve } \\
\text { damaged } \\
\text { image }\end{array}$ \\
\hline
\end{tabular}

TABLE 1: Walmart's Katrina Assistance

\begin{tabular}{|c|c|c|c|c|}
\hline Actors & Resources & Activities & Objectives & Results \\
\hline Infosys & $\begin{array}{c}\text { Industry } \\
\text { expertise, } \\
\text { IT educators } \\
\text { (professional } \\
\text { and staff } \\
\text { volunteers), } \\
\text { education } \\
\text { materials }\end{array}$ & $\begin{array}{l}\text { Provides } \\
\text { materials \& } \\
\text { methods, } \\
\text { trains faculty, } \\
\text { provides } \\
\text { seminars for } \\
\text { students }\end{array}$ & $\begin{array}{l}\text { Increase pool } \\
\text { of IT talent, } \\
\text { support higher } \\
\text { education } \\
\text { development }\end{array}$ & $\begin{array}{l}\text { Increase } \\
\text { in talent, } \\
\text { positive } \\
\text { community } \\
\text { and labor } \\
\text { engagement, } \\
\text { increase in } \\
\text { visibility }\end{array}$ \\
\hline Universities & $\begin{array}{l}\text { Faculty with } \\
\text { basic skills, } \\
\text { access to } \\
\text { students }\end{array}$ & $\begin{array}{l}\text { Sends faculty, } \\
\text { implements } \\
\text { and adapts } \\
\text { modules, } \\
\text { recruits student } \\
\text { participants }\end{array}$ & $\begin{array}{l}\text { Better quality } \\
\text { education } \\
\text { offerings, } \\
\text { better trained } \\
\text { graduates }\end{array}$ & $\begin{array}{c}\text { Meet } \\
\text { education } \\
\text { needs } \\
\text { of their } \\
\text { communities }\end{array}$ \\
\hline
\end{tabular}

TABLE 2: Infosys's Campus Connect 


\begin{tabular}{|c|c|c|c|c|}
\hline Actors & Resources & Activities & Objectives & Results \\
\hline Unilever & $\begin{array}{l}\text { Consumer } \\
\text { products }\end{array}$ & $\begin{array}{l}\text { Selling to } \\
\text { Shakti ammas } \\
\text { (female } \\
\text { entrepreneurs) }\end{array}$ & $\begin{array}{c}\text { Market share, } \\
\text { branding, } \\
\text { sustainable } \\
\text { investment } \\
\text { opportunities } \\
\text { for rural } \\
\text { women }\end{array}$ & $\begin{array}{c}\text { New } \\
\text { consumers } \\
\text { in } \\
\text { previously } \\
\text { inaccessible } \\
\text { rural } \\
\text { markets }\end{array}$ \\
\hline $\begin{array}{l}\text { Self-Help } \\
\text { Groups }\end{array}$ & $\begin{array}{l}\text { Access to } \\
\text { Shakti amma, } \\
\text { money to lend } \\
\text { to members }\end{array}$ & $\begin{array}{l}\text { Selecting } \\
\text { Shakti amma, } \\
\text { lending } \\
\text { money to } \\
\text { Shakti amma }\end{array}$ & $\begin{array}{c}\text { Increase } \\
\text { standard of } \\
\text { living for Shakti } \\
\text { amma }\end{array}$ & $\begin{array}{l}\text { Additional } \\
\text { income for } \\
\text { Shakti amma }\end{array}$ \\
\hline NGOs & $\begin{array}{l}\text { Content for } \\
\text { iShakti }\end{array}$ & $\begin{array}{c}\text { Creating } \\
\text { content for } \\
\text { iShakti portal }\end{array}$ & $\begin{array}{l}\text { Increase } \\
\text { standard of } \\
\text { living for } \\
\text { villagers }\end{array}$ & $\begin{array}{l}\text { Villagers } \\
\text { have } \\
\text { Internet } \\
\text { access } \\
\text { for more } \\
\text { informed } \\
\text { decision- } \\
\text { making }\end{array}$ \\
\hline $\begin{array}{l}\text { State and } \\
\text { Local } \\
\text { Governmental } \\
\text { Agencies }\end{array}$ & $\begin{array}{c}\text { Hardware } \\
\text { infrastructure, } \\
\text { funding }\end{array}$ & $\begin{array}{l}\text { Providing } \\
\text { desktop } \\
\text { computer, } \\
\text { dial-up } \\
\text { connection, } \\
\text { and funding }\end{array}$ & $\begin{array}{l}\text { Increase } \\
\text { standard of } \\
\text { living for } \\
\text { villagers }\end{array}$ & $\begin{array}{l}\text { Villagers } \\
\text { have } \\
\text { Internet } \\
\text { access } \\
\text { for more } \\
\text { informed } \\
\text { decision- } \\
\text { making }\end{array}$ \\
\hline
\end{tabular}

TABLE 3: Unilever's Project Shakti

\section{Analysis and Results}

We checked articles and periodicals in Academic Search Complete (EBSCO), ProQuest, and LexisNexis (AllNews) with word searches to capture articles related to the identified CSR activities. We examined these three databases to balance U.S. and international media coverage. Our dataset included all positive media coverage related to 1) Walmart's Katrina Assistance, 2) Infosys's Campus Connect, and 3) Unilever's Project Shakti. We investigated the time period from CSR event launch until the end of 2015 because media coverage had largely subsided by then. For Unilever's Project Shakti, however, we continued through to August 31, 2017 as there was substantial coverage in 2016 and 2017. 
To control for bias related to the MNEs' self-generated marketing, we eliminated MNE-generated press releases, including annual report narratives. Our dataset thus came from external independent media.

Since the MNEs in our dataset were of different sizes, we scaled positive media coverage by controlling for each firm's total media coverage. Specifically, we collected data on all articles that mentioned the MNE and calculated CSR-related positive media coverage as a percentage of overall media coverage (f). This percentage thus represented the positive media coverage attributed to the CSR activity.

$\frac{\% \text { positive media coverage for }}{\operatorname{CSR}_{\mathrm{it}}}=\frac{\begin{array}{l}\text { \# of CSR-related positive media } \\ \text { articles generated for MNEi }\end{array}}{\text { Total \# of MNE i media articles }}$

Where:

$i=$ Walmart (WMT), Infosys (INFY), or Unilever (UNL)

$t=$ year $\mathrm{t}_{1}^{\mathrm{n}}$

Panel A: Katrina Assistance effect on Walmart's positive media coverage

\begin{tabular}{|c|c|c|c|}
\hline Year & $\begin{array}{c}\text { \# of } \\
\text { articles } \\
\text { WMT }\end{array}$ & $\begin{array}{c}\text { \# of positive } \\
\text { articles related to } \\
\text { WMT's Katrina } \\
\text { assistance effort }\end{array}$ & $\begin{array}{c}\text { \% positive } \\
\text { media } \\
\text { coverage }\end{array}$ \\
\hline 2005 & 6,989 & 60 & $0.8585 \%$ \\
\hline 2006 & 21,934 & 18 & $0.0821 \%$ \\
\hline 2007 & 16,120 & 6 & $0.0372 \%$ \\
\hline 2008 & 13,330 & 7 & $0.0525 \%$ \\
\hline 2009 & 21,940 & 2 & $0.0091 \%$ \\
\hline 2010 & 34,313 & 2 & $0.0058 \%$ \\
\hline 2011 & 39,504 & 3 & $0.0076 \%$ \\
\hline 2012 & 38,812 & 3 & $0.0077 \%$ \\
\hline 2013 & 41,242 & 0 & $0.0000 \%$ \\
\hline 2014 & 39,023 & 4 & $0.0103 \%$ \\
\hline 2015 & 35,813 & 5 & $0.0140 \%$ \\
\hline Total & $\mathbf{3 0 9 , 0 2 0}$ & $\mathbf{1 1 0}$ & $\mathbf{0 . 0 3 5 6 \%}$ \\
\hline & & & \\
\hline
\end{tabular}




\begin{tabular}{|c|c|c|c|}
\hline Panel B: Campus Connect effect on Infosys's positive media coverage \\
\hline Year & $\begin{array}{c}\text { \# of } \\
\text { articles } \\
\text { INFY }\end{array}$ & $\begin{array}{c}\text { \# of positive } \\
\text { articles related } \\
\text { to INFY's Campus } \\
\text { Connect }\end{array}$ & $\begin{array}{c}\text { \% positive } \\
\text { media } \\
\text { coverage }\end{array}$ \\
\hline 2004 & 326 & 1 & $0.3067 \%$ \\
\hline 2005 & 385 & 1 & $0.2597 \%$ \\
\hline 2006 & 462 & 6 & $1.2987 \%$ \\
\hline 2007 & 370 & 11 & $2.9730 \%$ \\
\hline 2008 & 289 & 8 & $2.7682 \%$ \\
\hline 2009 & 292 & 4 & $1.3699 \%$ \\
\hline 2010 & 303 & 3 & $0.9901 \%$ \\
\hline 2011 & 261 & 13 & $4.9808 \%$ \\
\hline 2012 & 133 & 3 & $2.2556 \%$ \\
\hline 2013 & 144 & 6 & $4.1667 \%$ \\
\hline 2014 & 141 & 5 & $3.5461 \%$ \\
\hline 2015 & 109 & 3 & $2.7523 \%$ \\
\hline Total & $\mathbf{3 , 2 1 5}$ & $\mathbf{6 4}$ & $\mathbf{1 . 9 9 0 7 \%}$ \\
\hline
\end{tabular}

Panel C: Project Shakti's effect on Unilever's positive media coverage

\begin{tabular}{|c|c|c|c|}
\hline Year & $\begin{array}{c}\text { \# of } \\
\text { articles } \\
\text { UNL }\end{array}$ & $\begin{array}{c}\text { \# of positive } \\
\text { articles related } \\
\text { to UNL's Project } \\
\text { Shakti }\end{array}$ & $\begin{array}{c}\text { \% positive } \\
\text { media } \\
\text { coverage }\end{array}$ \\
\hline 2003 & 3,898 & 2 & $0.0513 \%$ \\
\hline 2004 & 4,943 & 4 & $0.0809 \%$ \\
\hline 2005 & 5,401 & 3 & $0.0555 \%$ \\
\hline 2006 & 5,397 & 7 & $0.1297 \%$ \\
\hline 2007 & 5,389 & 7 & $0.1299 \%$ \\
\hline 2008 & 5,037 & 6 & $0.1191 \%$ \\
\hline 2009 & 5,366 & 13 & $0.2423 \%$ \\
\hline 2010 & 6,695 & 17 & $0.2539 \%$ \\
\hline
\end{tabular}


Panel C: Project Shakti's effect on Unilever's positive media coverage

\begin{tabular}{|c|c|c|c|}
\hline 2011 & 7,951 & 23 & $0.2893 \%$ \\
\hline 2012 & 7,209 & 14 & $0.1942 \%$ \\
\hline 2013 & 7,848 & 19 & $0.2421 \%$ \\
\hline 2014 & 8,529 & 11 & $0.1290 \%$ \\
\hline 2015 & 8,025 & 12 & $0.1495 \%$ \\
\hline 2016 & 8,436 & 11 & $0.1304 \%$ \\
\hline 2017 & 5,938 & 3 & $0.0505 \%$ \\
\hline Total & $\mathbf{9 6 , 0 6 2}$ & $\mathbf{1 5 2}$ & $\mathbf{0 . 1 5 8 2} \%$ \\
\hline
\end{tabular}

TABLE 4: Impact of NFP alliance on WMT, INFY, and UNL Positive Media Coverage

\begin{tabular}{|c|c|c|c|}
\hline Year & $\begin{array}{c}\text { \% positive } \\
\text { media } \\
\text { coverage } \\
\text { WMT: Katrina } \\
\text { Hurricane } \\
\text { relief }\end{array}$ & $\begin{array}{c}\text { \% positive } \\
\text { media coverage } \\
\text { INFY: Campus } \\
\text { Connect }\end{array}$ & $\begin{array}{c}\text { \% positive } \\
\text { media } \\
\text { coverage UNL: } \\
\text { Project Shakti }\end{array}$ \\
\hline 2003 & - & - & $\mathbf{0 . 0 5 1 3 \%}$ \\
\hline 2004 & - & $\mathbf{0 . 3 0 6 7 \%}$ & $0.0809 \%$ \\
\hline 2005 & $\mathbf{0 . 8 5 8 5 \%}$ & $0.2597 \%$ & $0.0555 \%$ \\
\hline 2006 & $0.0821 \%$ & $\mathbf{1 . 2 9 8 7 \%}$ & $0.1297 \%$ \\
\hline 2007 & $0.0372 \%$ & $\mathbf{2 . 9 7 3 0 \%}$ & $0.1299 \%$ \\
\hline 2008 & $0.0525 \%$ & $\mathbf{2 . 7 6 8 2 \%}$ & $0.1191 \%$ \\
\hline 2009 & $0.0091 \%$ & $\mathbf{1 . 3 6 9 9 \%}$ & $0.2423 \%$ \\
\hline 2010 & $0.0058 \%$ & $\mathbf{0 . 9 9 0 1 \%}$ & $0.2539 \%$ \\
\hline 2011 & $0.0076 \%$ & $\mathbf{4 . 9 8 0 8 \%}$ & $0.2893 \%$ \\
\hline 2012 & $0.0077 \%$ & $\mathbf{2 . 2 5 5 6 \%}$ & $0.1942 \%$ \\
\hline 2013 & $0.0000 \%$ & $\mathbf{4 . 1 6 6 7 \%}$ & $0.2421 \%$ \\
\hline 2014 & $0.0103 \%$ & $\mathbf{3 . 5 4 6 1 \%}$ & $0.1290 \%$ \\
\hline 2015 & $0.0140 \%$ & $\mathbf{2 . 7 5 2 3 \%}$ & $0.1495 \%$ \\
\hline 2016 & - & $\mathbf{1 . 2 5 0 0 \%}$ & $0.1304 \%$ \\
\hline 2017 & - & $\mathbf{0 . 5 3 4 8 \%}$ & $0.0505 \%$ \\
\hline
\end{tabular}

TABLE 5: Comparative Positive Media Coverage

* Highest \% in bold 
Walmart's Katrina Assistance. Panel A of Table 4 reports the positive media coverage for Walmart's Katrina Assistance. Consistent with Proposition 1, Walmart received substantial positive media coverage soon after the disaster. From August 30 to December 31, 2005, Walmart's Katrina Assistance was intensely covered by the media (60 articles in four months) and accounted for almost one percent $(0.8585 \%)$ of the firm's total media coverage during the period. There was sustained positive media coverage until late 2006 , with a final decline from 0.08 percent in 2006 to 0.014 percent in 2015. Thus, Walmart's matched alliance with the Red Cross during Hurricane Katrina resulted in positive media coverage, supporting Proposition 1.

Infosys's Campus Connect. Panel B of Table 4 shows the positive media coverage generated by Infosys's Campus Connect, which is also consistent with Proposition 1. Soon after the Campus Connect announcement, 0.31 percent of Infosys's media coverage from April ${ }^{1}$ to December 2004 was positive coverage related to Campus Connect. This continued in 2005, 2006, and 2007, with 0.26, 1.30, and 2.97 percent positive media coverage, respectively, about Campus Connect. In 2011, positive media coverage reached the highest point-4.17 percent-which correlates with the visibility of Campus Connect graduates and numerous awards around 2011. Infosys's matched alliance with universities to train and develop IT talent resulted, therefore, in positive media coverage, supporting Proposition 1.

Unilever's Project Shakti. Unilever's Project Shakti did not receive too much positive media coverage at its inception in 2003. In fact, the peak occurred 8 years after its establishment when it had 23 articles $(0.2893$ percent) in 2012. Consistent with Proposition 1, Project Shakti generated a total of 152 articles from 2003 until 2017, and Panel C in Table 4 shows that CSR-related media coverage for the project accounted for less than one percent of overall media coverage across all years, accounting for 0.2 percent on average. However, Unilever is a huge global conglomerate that generates considerable press (both positive and negative); thus, 152 articles is not a big number. At the same time, Project Shakti had longterm implications-un-tabulated results show that during 2010, 2011, 2012, and 2013, Shakti generated 17, 23, 14, and 19 articles respectively, with substantial coverage continuing even in 2017.

It is also worth noting that Project Shakti was deliberately focused on rural India, and that more than 90 percent of the positive media coverage was generated there. Thus, Project Shakti generated a much stronger positive response within India than can be construed as a percentage

${ }^{1}$ The Campus Connect initiative was announced on April 15, 2004. 
of Unilever's global media coverage. Unilever's matched alliance with state and local governments, NGOs, and self-help groups in support of Project Shakti resulted therefore in CSR-related positive media coverage, supporting Proposition 1.

In sum, all three case studies (Walmart's Katrina Assistance, Infosys's Campus Connect, and Unilever's Project Shakti) support Proposition 1 as they generated positive media coverage and, most importantly, improved many lives.

The Role of MNE Country of Origin and Geographic Location. To test Proposition 2, we compared the media coverage generated by Walmart and Infosys (both of which were local MNEs in their CSR locations) with the media coverage generated by Unilever (which was a foreign MNE in India). In the first twelve years after the CSR activity, local MNEs generate more positive media coverage than do foreign MNEs, although this appears to be driven by Infosys. Walmart received positive media coverage for the first four years after its CSR activity, but this tapered off subsequently. Unilever's Project Shakti did not initially generate as much positive media coverage as the other two activities did, although this increased in subsequent years. Thus, the results generally support Proposition 2, with one qualification being how soon after the CSR activity the positive media coverage is being investigated. The local MNEs - Infosys and Walmart—received stronger positive media coverage (vs. the foreign MNE, Unilever). As noted, however, the results suggest that the effect of Unilever's Project Shakti seems to be more persistent.

To test Proposition 3, we compared the positive media coverage generated by Walmart (which did its CSR activity in the developed United States market as a local MNE) with the positive media coverage generated by Infosys (which did its CSR activity in the emerging Indian market as a local MNE). Our findings suggest that, consistent with Proposition 3, local MNEs generate more CSR-related positive media coverage in an emerging (vs. developed) market. The graph below shows the substantial media coverage that Infosys's Campus Connect generated and that Walmart's Katrina Assistance initially generated before losing momentum, along with the less substantial media coverage that Unilever's Project Shakti initially generated before gradually picking up momentum. 
$\%$ of positive media coverage for WMT, INFY, \& UNL

attributable to CSR alliance

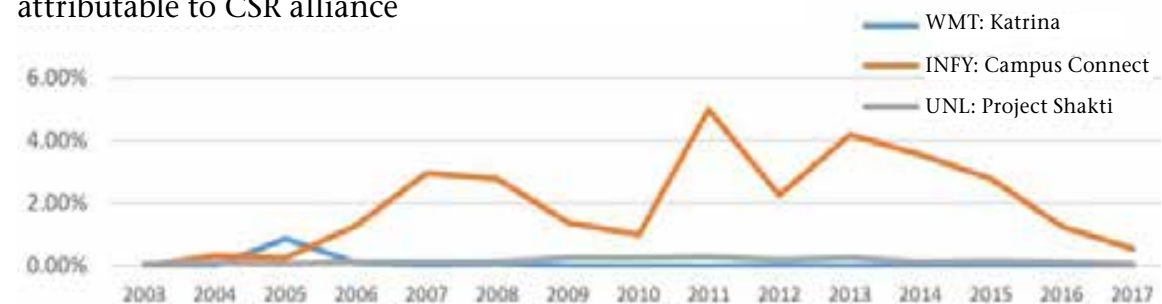

\% Positive Media Coverage for WMT, INFY, and UNL

\section{CONCLUSION}

This study provides evidence to suggest that CSR activities from matched MNE-NFP alliances result in positive media coverage. Our results also show that such coverage depends on the MNE country of origin (local/foreign) and the country of CSR activity (emerging/ developed). Positive media coverage is greater for local (vs. foreign) MNEs and in emerging (vs. developed) markets.

The literature that examines the effect of alliance-based CSR activities is scarce and remains understudied (Keys et al., 2009). The underlying conditions for effective CSR activities as they relate to the interplay between matched MNE-NFP alliances, business strategy and processes, and the setting in which these occur have not been explored in previous CSR research. Our study addresses these gaps by examining the impact of strategically matched MNE-NFP alliances in local (domestic) versus foreign contexts and in developed versus emerging markets. Finally, many CSR initiatives fail to meet their desired objectives (Browne \& Nuttall, 2013) or these objectives fail to be measured. Our study provides guidance that enhances the measurement and effectiveness of alliancebased CSR, thereby furthering the social justice aims of the Society of Jesus.

In this study, we propose a model that provides MNE management with a roadmap toward developing collaborations and matched alliances with NFP organizations so as to measure and increase effectively the benefits of CSR activities. We argue that by partnering with NFPs in alliances that "match" common objectives with complementary capabilities, MNEs can increase market legitimacy, business process capabilities, or both, resulting in positive outcomes for CSR initiatives. Moreover, our case and media-intensity analysis shows increased media coverage surrounding a CSR event when MNEs partner with matched 
local NFPs. These results are influenced by the setting in which they occur and are greater for local (vs. foreign) MNEs and for local MNEs in emerging (vs. developed) markets. Our findings thus provide useful guidance on how to engage effectively in alliance-based CSR activities that enhance measurable outcomes and societal benefits for the MNEs and NFPs involved.

\section{Implications}

Santos and Laczniak (2009) propose the integrative justice model (IJM; Santos, 2013) to allow for a more positive form of capitalism as MNEs from developed markets engage in emerging markets. Our findings, however, suggest some issues unaddressed by the IJM. First, we focus on CSR activities to serve consumers (vs. considering them purely as market segments). Next, we focus on the role of alliances while engaging in CSR activities. Finally, we emphasize matched alliances with NFPs rather than alliances with other MNEs. The results of our study imply that MNEs, by partnering with NFPs, can heed Pope Francis's call and benefit consumers, MNEs, and NFPs.

Previous articles in this journal have investigated sustainability as a response to the Holy Father's appeal (e.g., Imanaka, Prussia, \& Alexis, 2017; Kennedy \& Santos, 2017). Our results suggest that while sustainability is a solution, MNEs can be most successful in implementing it by partnering with other NFPs rather than by doing it themselves or with other MNEs. To achieve the greatest possible success, MNEs can also focus their efforts in local or emerging markets.

\section{Limitations and Suggested Future Research}

Our study, like all research, has shortcomings and unresolved questions. First, our results suggest that CSR activities relying on NFP matched alliances might benefit from legitimacy due to the NFP or increased business performance or both. However, we are unable to tease apart these influences. Moreover, although we used case and mediaintensity analysis, we do not have traditional quantitative data that can permit stronger statistical claims.

We were also unable to identify an appropriate case study for a foreign MNE in a developed market, and so our actual case studies employed only a partial factorial design. Our test of foreign MNEs vs. local MNEs, therefore, used only one foreign MNE but two local MNEs. In addition, our test of developed vs. emerging markets was limited only to local MNEs rather than being generalizable independent of 
MNE country of origin. Despite these limitations, however, our work provides a platform for future research to extend our understanding of factors that can enhance positive outcomes for matched alliance-based CSR initiatives.

\section{REFERENCES}

Aaker, J., Vohs, K. D., \& Mogilner, C. 2010. Nonprofits are seen as warm and forprofits as competent: Firm stereotypes matter. Journal of Consumer Research, 37(2): 224-237.

Ashforth, B. E., \& Mael, F. A. 1996. Organizational identity and strategy as a context for the individual. Advances in Strategic Management, 13: 19-64.

Brancatelli, R. 2016. Laudato si' and a spirituality of resiliency. Journal of Management for Global Sustainability, 4(1): 15-28.

Browne, J., \& Nuttall, R. 2013. Beyond corporate social responsibility: Integrated external engagement. The McKinsey Quarterly (March): 1-11.

Calfee, J. E. 1986. The ghost of cigarette advertising past. Regulation, 10(2): 35-45. Choi, J., Chang, Y. K., Li, Y. J., \& Jang, M. G. 2016. Doing good in another neighborhood: Attributions of CSR motives depend on corporate nationality and cultural orientation. Journal of International Marketing, 24(4): 82-102.

Costa, J. E. R., \& Martí, J. M. R. (Eds.). 2012. Towards a new theory of the firm: Humanizing the firm and the management profession. Bilbao, Spain: Fundacion BBVA.

Cruz, L. B., \& Boehe, D. M. 2010. How do leading retail MNCs leverage CSR globally? Insights from Brazil. Journal of Business Ethics, 91(2): 243-263.

David, S. 2009. Infosys's Campus Connect: Skilled effort. India Today (Oct 9).

Delmas, M. A., \& Burbano, V. C. 2011. The drivers of greenwashing. California Management Review, 54(1): 64-87.

Dunning, J. H. 1977. Trade, location of economic activity and the MNE: A search for an eclectic approach. In B. Ohlin, P.-O. Hesselborn, \& P. M. Wijkman (Eds.), The international allocation of economic activity: 395-418. London: Palgrave Macmillan.

Elg, U., Ghauri, P. N., \& Tarnovskaya, V. 2008. The role of networks and matching in market entry to emerging retail markets. International Marketing Review, 25(6): 674-699.

Ellen, P. S., Webb, D. J., \& Mohr, L. A. 2006. Building corporate associations: Consumer attributions for corporate socially responsible programs. Journal of the Academy of Marketing Science, 34(2): 147-157.

Fein, S. 1996. Effects of suspicion on attributional thinking and the correspondence bias. Journal of Personality and Social Psychology, 70(6): 1164-1184.

Francis. 2015. Laudato si': On care for our common home. Vatican City: Libreria Editrice Vaticana.

Frost, S., \& Burnett, M. 2007. Case study: The Apple iPod in China. Corporate Social Responsibility and Environmental Management, 14(2): 103-113. 
Garriga, E., \& Melé, D. 2004. Corporate social responsibility theories: Mapping the territory. Journal of Business Ethics, 53(1-2): 51-71.

Gilbert, D. T., \& Malone, P. S. 1995. The correspondence bias. Psychological Bulletin, 117(1): 21-38.

Groza, M. D., Pronschinske, M. R., \& Walker, M. 2011. Perceived organizational motives and consumer responses to proactive and reactive CSR. Journal of Business Ethics, 102(4): 639-652.

Gürhan-Canli, Z., \& Maheswaran, D. 2000. Cultural variations in country of origin effects. Journal of Marketing Research, 37(3): 309-317.

Hakim, D., \& Bradsher, K. 2015. After Volkswagen revelation, auto emissions tests come under global scrutiny. The New York Times (Sept. 24).

Harriss-White, B. 2006. Poverty and capitalism. Economic and Political Weekly, 41(13): 1241-1246.

Hofstede, G. 2001. Culture's consequences: Comparing values, behaviors, Institutions, and organizations across nations (2nd ed.). Thousand Oaks, CA: Sage Publications.

Hsu, K. T. 2012. The advertising effects of corporate social responsibility on corporate reputation and brand equity: Evidence from the life insurance industry in Taiwan. Journal of Business Ethics, 109(2): 189-201.

Husted, B. W., \& Allen, D. B. 2006. Corporate social responsibility in the multinational enterprise: Strategic and institutional approaches. Journal of International Business Studies, 37(6): 838-849.

Imanaka, J. L., Prussia, G., \& Alexis, S. 2017. Laudato si' and integral ecology: A reconceptualization of sustainability. Journal of Management for Global Sustainability, 5(1), http://dx.doi.org/10.13185/JM2017.05102.

Infosys. 2017a. Campus Connect-fast facts FY17 Jan' 17. Bengaluru, India: Infosys. Infosys. 2017b. Infosys Campus Connect. Available at https://campusconnect. infosys.com/faq.aspx

Iyengar, S. S., Lepper, M. R., \& Ross, L. 1999. Independence from whom? Interdependence with whom? Cultural perspectives on ingroups versus outgroups. In D. A. Prentice \& D. T. Miller (Eds.), Cultural divides: Understanding and overcoming group conflict: 273-301. New York: Russell Sage Foundation.

Kennedy, A. A., \& Santos, N. J. C. 2017. The papal encyclical Laudato si': A focus on sustainability attentive to the poor. Journal of Management for Global Sustainability, 5(1), http://dx.doi.org/10.13185/JM2017.05103.

Keys, T., Malnight, T. W., \& Van der Graaf, K. 2009. Making the most of corporate social responsibility. The McKinsey Quarterly (December): 1-8.

Lancaster, J. 2006. Building wealth by the penny; in rural India, a sales force in saris delivers soap, social change. The Washington Post (March 14): A.13.

Neff, J. 2005. Katrina brings out Wal-Mart's inner good guy. Advertising Age (Sept. 12).

Nisbett, R. E., \& Ross, L. 1980. Human inference: Strategies and shortcomings of social judgment. Englewood Cliffs, NJ: Prentice Hall.

Polonsky, M., \& Jevons, C. 2009. Global branding and strategic CSR: An overview of three types of complexity. International Marketing Review, 26(3): 327-347. 
Santos, N. J. C. 2013. Social entrepreneurship that truly benefits the poor: An integrative justice approach. Journal of Management for Global Sustainability, 1(2): 31-62.

Santos, N. J. C., \& Laczniak, G. R. 2009. Marketing to the poor: An integrative justice model for engaging impoverished market segments. Journal of Public Policy \& Marketing, 28(1): 3-15.

Schwenk, C. R. 1990. Conflict in organizational decision making: An exploratory study of its effects in for-profit and not-for-profit organizations. Management Science, 36(4): 436-448.

Sen, S., \& Bhattacharya, C. B. 2001. Does doing good always lead to doing better? Consumer reactions to corporate social responsibility. Journal of Marketing Research, 38(2): 225-243.

Society of Jesus. 2016. Justice in the global economy: Building sustainable and inclusive communities. Promotio Iustitiae, 121(1).

Stoner, J. A. F. 2013. What we want this Journal to be. Journal of Management for Global Sustainability, 1(1): 1-6.

Tajfel, H., \& Turner, J. C. 1979. An integrative theory of intergroup conflict. In W. G. Austin \& S. Worchel (Eds.), The social psychology of intergroup relations: 33-47. California: Brooks/Cole.

Torelli, C. J., Monga, A. B., \& Kaikati, A. M. 2012. Doing poorly by doing good: Corporate social responsibility and brand concepts. Journal of Consumer Research, 38(5): 948-963.

Unilever. 2001. Hindustan Unilever Limited: Report and accounts 2001. Rotterdam, Netherlands / London: Unilever.

Unilever. 2005. For Rojamma, Project Shakti means being able to educate her daughters. Rotterdam, Netherlands / London: Unilever.

van Beurden, P., \& Gössling, T. 2008. The worth of values-a literature review on the relation between corporate social and financial performance. Journal of Business Ethics, 82(2): 407-424.

Varadarajan, P. R., \& Menon, A. 1988. Cause-related marketing: A coalignment of marketing strategy and corporate philanthropy. The Journal of Marketing, 52(3): 58-74.

Wachtel, H. M. 1972. Capitalism and poverty in America: Paradox or contradiction? The American Economic Review, 62(1/2): 187-194.

Wettstein, F. 2005. From causality to capability. Journal of Corporate Citizenship, (19): 105-117.

Yuan, W., Bao, Y., \& Verbeke, A. 2011. Integrating CSR initiatives in business: An organizing framework. Journal of Business Ethics, 101(1): 75-92. 
Marinilka B. Kimbro received a Ph.D. in Accounting from the University of Maryland, College Park. Her scholarship examines the role of information in decision-making, capital markets' development, institutions, and society. Her research attempts to generate "engaged scholarship" that is relevant to her teaching, the profession, and expresses Seattle University's mission of social justice.

Ajay T. Abraham received a Ph.D. in Marketing from the University of Maryland, College Park. His research focuses on pricing, perceptual salience, and morality. He has published in MIT Sloan Management Review and has forthcoming publications in Journal of Marketing Research and Journal of Business and Industrial Marketing.

C. Jay Lambe received a Ph.D. in Marketing from the Darden Graduate School of Business, University of Virginia. His research focuses on the development and management of business-to-business relationships and on the theory of the firm. He is editorial Review Board Member for Industrial Marketing Management, Journal of Business Research, and Journal of Business-to-Business Marketing.

Victoria Jones is the Chief Global Affairs Officer at the University of California, Irvine, where she oversees global strategy, campus coordination, and institutional engagement. She received her Ph.D. in Intercultural Communication and Marketing from Cornell University. Her research explores the interaction of culture, business, and society. 